\title{
Lumbar Bone Mineral Density and Insulin-like Growth Factor Binding Protein-3 in Japanese Collegiate Women
}

\author{
Noriko Miyamoto ${ }^{a}$ and Hiroyuki Imamura ${ }^{*}, b$ \\ ${ }^{a}$ Faculty of Health and Welfare, Nishikyushu University, 4490-9 Ozaki, Kanzaki-machi, Kanzaki 842-8585, Japan and ${ }^{b}$ Faculty of \\ Health Management, Department of Health and Nutrition, Nagasaki International University, 2825-7 Huis Ten Bosch, Sasebo 859- \\ 3298, Japan
}

(Received October 29, 2009; Accepted April 28, 2010; Published online May 17, 2010)

\begin{abstract}
The purpose of this study was to investigate the relationship between lumbar bone mineral density (BMD) and insulin-like growth factor binding protein-3 (IGFBP-3) level in 55 collegiate women. In univariate analyses, body weight, body mass index (BMI), waist circumference, maximal oxygen uptake $\left(\dot{\mathrm{V}} \mathrm{O}_{2} \mathrm{max}\right)$ in $\mathrm{L} \cdot \mathrm{min}^{-1}$, and IGFBP-3 level were significantly positively correlated, while serum calcium $(\mathrm{Ca})$ level was significantly negatively correlated with lumbar BMD. Multiple regression analysis was performed with lumbar BMD as a dependent variable and body weight, BMI, waist circumference, $\mathrm{V}_{2} \max$ in $\mathrm{L} \cdot \mathrm{min}^{-1}$, and serum levels of IGFBP-3 and $\mathrm{Ca}$ as independent variables. Lumbar BMD was significantly positively correlated with body weight, $\mathrm{V}_{2} \mathrm{max}_{\text {in }}$ $\mathrm{L} \cdot \mathrm{min}^{-1}$, and IGFBP-3 level, while negatively correlated with serum $\mathrm{Ca}$ level. The subjects were divided into 3 groups in accordance with IGFBP-3 level. After adjusting for body weight, $\mathrm{V}_{2} \mathrm{max}$ in $\mathrm{L} \cdot \mathrm{min}^{-1}$, and serum Ca level in the analysis of covariance, the group with the highest IGFBP-3 had significantly higher lumbar BMD than the lowest group. The results indicate that the known association of IGFBP-3 with lumbar BMD in older adults is already apparent in young women.
\end{abstract}

Key words _ lumbar bone mineral density, growth hormone, insulin-like growth factor-1, insulin-like growth factor binding protein-3, sex hormone

\section{INTRODUCTION}

Growth hormone $(\mathrm{GH})$ is secreted by the pituitary gland and stimulates the synthesis of insulinlike growth factor-1 (IGF-1) by the liver. IGF1 is also produced locally and has autocrine and paracrine activities. The circulating IGF-1 is the major effector of bone growth and exhibits its mitogenic activity by mediating most of the physiological actions of GH. ${ }^{1,2)}$ The majority of circulating IGF-1 is bound to IGF binding protein3 (IGFBP-3), which is the quantitatively predominant IGFBP in circulation. Decreased levels of IGF-1 and IGFBP-3 have been reported in osteoporosis patients. ${ }^{3,4)}$ Levels of IGF-1 and IGFBP3 decline with age, however, IGFBP-3 is more

*To whom correspondence should be addressed: Faculty of Health Management, Department of Health and Nutrition, Nagasaki International University, 2825-7 Huis Ten Bosch, Sasebo 859-3298, Japan. Tel. \& Fax: +81-956-20-5838; Email: himamura@niu.ac.jp strongly associated with the presence of vertebral fractures than IGF-1 and age in postmenopausal women. ${ }^{5)}$ In some studies, no association has been found between IGF-1 level and bone mineral density (BMD) in men or women, ${ }^{6-8)}$ while in other studies positive relationships were found between IGF-1 and/or IGFBP-3 level and BMD in men. ${ }^{9-14)}$ However, these data are mainly based on studies of middle-aged or older individuals conducted in Western countries. Thus, it is difficult to extrapolate these findings to young Japanese women at an age when bone mass reaches its peak. ${ }^{15}$ )

Many factors related to BMD and/or IGF-1 level have been identified, which include physical fitness, ${ }^{16)}$ physical activity, ${ }^{17-19)}$ dietary and nutrient intake, ${ }^{17-20)}$ body weight, ${ }^{21,22)}$ cigarette smoking, ${ }^{22)}$ alcohol intake, ${ }^{23)}$ and sex hormone. ${ }^{24)}$ The purpose of this study was to investigate the relationship between IGFBP-3 level and lumbar BMD in young women, controlling or statistically adjusting for these confounding factors. 


\section{MATERIALS AND METHODS}

\section{Subjects and Self-administered Question-} naire —_ Fifty-five collegiate women were recruited from one university and consented to undergo the study procedure after explanation of the purpose of the study. To be included in the study, they had to meet the following criteria: they were menstruating at normal intervals, ranging from 26-31 days, which falls within the normally accepted range; ${ }^{25)}$ they drank alcohol less than once a week and even then only had a small amount; they were not on any medication at the time of their participation in the study; and they had never taken birth control pills. The study protocol was approved by the Ethics Committee of Nakamura Gakuen University and informed consent was obtained from each subject.

A few days before blood sampling, information on physical activity was obtained via a selfadministered questionnaire. The accuracy of the questionnaire was checked through individual interviews. The frequency, duration, and mode of physical activity were checked, and scores of 1-5 were given according to Young and Steinhardt, ${ }^{26)}$ who reported a significant correlation $(r=0.57)$ between maximal time on the treadmill and activity scores of 1-5. In brief, the scores $1-5$ were as follows: 1 = low activity, $2=$ moderate activity, $3=$ less than $60 \mathrm{~min}$ per week of vigorous activity, $4=1-6 \mathrm{hr}$ per week of vigorous activity, and $5=$ more than $6 \mathrm{hr}$ per week of vigorous activity.

Measurements — Body weight and height were measured with the subjects in underwear to the nearest $0.1 \mathrm{~kg}$ and $0.1 \mathrm{~cm}$, respectively. The body mass index (BMI) was expressed as weight $/$ height $^{2}$ $\left(\mathrm{kg} / \mathrm{m}^{2}\right)$.

Lumbar BMD (L2-L4) was measured with dual-energy X-ray absorptiometry (Lunar Radiation Co., WI, U.S.A.).

Maximal oxygen uptake $\left(\dot{\mathrm{V}}_{2} \max \right)$ was measured with a continuous multistage exercise test to volitional exhaustion on a Monark bicycle ergometer. The test was conducted in air-conditioned facilities with the temperature set at $25^{\circ} \mathrm{C}$. Ventilatory measurements were made by standard open-circuit calorimetry (Wyvern Software Physiologic Exercise Testing System; P.K. Morgan Instruments, Inc., Andover, MA, U.S.A.) with $30 \mathrm{~s}$ sampling intervals. Details of the methods have been presented elsewhere. ${ }^{27)}$

Dietary information was collected using a 3- weekday diet record. Each diet was analyzed using a computer program. Each food item was coded according to the Tables of Japanese Foodstuff Composition. ${ }^{28)}$

Blood Analysis — Because GH and IGF-1 levels change throughout the menstrual cycle, ${ }^{29,30)}$ blood samples were obtained between days 7 and 9 of the menstrual cycle when estrogen levels were relatively low. ${ }^{25)}$ Physical exercise was not allowed $48 \mathrm{hr}$ prior to the blood sampling, and beverages other than water could not be consumed $24 \mathrm{hr}$ prior to the blood sampling. Subjects arrived at the laboratory by $08: 00$. The temperature of the laboratory was set at $25^{\circ} \mathrm{C}$. Fasting ( $12 \mathrm{hr}$ ) blood samples were drawn from the antecubital vein after each subject had been seated quietly for at least $20 \mathrm{~min}$. The samples were immediately stored on ice, and kept on ice until centrifugation within $10 \mathrm{~min}$ in a refrigerated centrifuge at $4^{\circ} \mathrm{C}$. Samples were stored in a freezer at $-80^{\circ} \mathrm{C}$ and were analyzed within 10 days by a local commercial laboratory (SRL Inc., Tokyo, Japan). All measurements were duplicated.

$\mathrm{GH},{ }^{31)}$ estradiol, ${ }^{32)}$ progesterone, ${ }^{33)}$ luteinizing hormone $(\mathrm{LH}),{ }^{34)}$ testosterone, ${ }^{35)}$ thyroidstimulating hormone (TSH), ${ }^{36)}$ IGFBP- $3,{ }^{37}$ and IGF-1 ${ }^{38)}$ in serum were measured by radioimmunoassay. Serum sex hormone binding globulin (SHBG), calcium (Ca), inorganic phosphate (IP), and magnesium were measured with immunoradiometric assay, ${ }^{39)}$ Orthocresolphthalein Complexone, ${ }^{40)}$ direct molybdenum, ${ }^{41}$ and Xylidyl Blue methods, ${ }^{42)}$ respectively.

Statistical Analysis — Statistical analyses were performed with SPSS for Windows (Version 17.0J; SPSS Inc., Chicago, IL, U.S.A.). Descriptive statistics included means and S.D. or S.E. Pearson correlation coefficients were used to examine simple correlations between 2 variables. Multiple regression analyses were performed. Because of the small sample size, the number of independent variables included in each model was limited to variables that showed significant correlation in the univariate analyses $(p<0.05)$ with lumbar BMD. In the multiple regression analysis, only variables that significantly $(p<0.05)$ contributed to the $\mathrm{R}^{2}$ were considered independent determinants of lumbar BMD. The subjects were divided into 3 groups in accordance with IGFBP-3 level in which approximately equal numbers of subjects were included in each group, and then analysis of covariance was performed to adjust mean values for possible influences of confounding factors. Two-sided $p<0.05$ was considered to be 
Table 1. Characteristics of Subjects and Biochemical Values $(n=55)$

\begin{tabular}{|c|c|c|c|c|}
\hline \multirow[b]{2}{*}{ Age (year) } & \multicolumn{2}{|c|}{ Mean \pm S.D. } & \multicolumn{2}{|c|}{ Standard value } \\
\hline & 20.7 & $\pm \quad 0.9$ & & \\
\hline Height $(\mathrm{cm})$ & 159.6 & $\pm \quad 4.5$ & 158.9 & $\pm 5.3^{a)}$ \\
\hline Weight $(\mathrm{cm})$ & 52.3 & $\pm \quad 5.2$ & $52.3=$ & $\pm \quad 6.0^{a)}$ \\
\hline BMI & 20.5 & $\pm \quad 1.7$ & $20.7=$ & $\pm \quad 2.2^{a)}$ \\
\hline$\%$ Fat & 26.2 & $\pm \quad 4.0$ & 28.4 & $\pm \quad 8.3^{b)}$ \\
\hline Waist (cm) & 70.4 & $\pm \quad 5.1$ & $65.0=$ & $\pm \quad 5.9^{a)}$ \\
\hline$\dot{\mathrm{V}} \mathrm{O}_{2} \max \left(\mathrm{ml} \cdot \min ^{-1}\right)$ & 2129 & \pm 481 & 2050 & $\pm 240^{a)}$ \\
\hline$\dot{\mathrm{V}}_{2} \max \left(\mathrm{ml} \cdot \mathrm{kg}^{-1} \cdot \min ^{-1}\right)$ & 40.9 & $\pm \quad 9.3$ & $36.4=$ & $\pm \quad 5.0^{a)}$ \\
\hline Lumbar BMD (g/cm²) & 1.162 & $\pm \quad 0.116$ & 1.192 & $\pm 0.146^{c)}$ \\
\hline $\mathrm{TSH}(\mu \mathrm{IU} / \mathrm{ml})$ & 1.84 & \pm 2.06 & 0.34 & $\sim 3.50^{d)}$ \\
\hline $\mathrm{GH}(\mathrm{ng} / \mathrm{ml})$ & 10.37 & $\pm \quad 8.28$ & 0.66 & $\sim 3.68^{d)}$ \\
\hline IGF-1 (ng/ml) & 278 & \pm 63 & 121 & $\sim 436^{d)}$ \\
\hline $\mathrm{LH}(\mathrm{mIU} / \mathrm{ml})$ & 4.0 & $\pm \quad 2.4$ & 1.8 & $\sim 7.6^{d)}$ \\
\hline Estradiol $\left(\mathrm{E}_{2}, \mathrm{pg} / \mathrm{ml}\right)^{*}$ & 46.0 & \pm 16.0 & 11 & $\sim 82^{d)}$ \\
\hline Progesterone $(\mathrm{P}, \mathrm{ng} / \mathrm{ml})^{* *}$ & 0.6 & $\pm \quad 0.2$ & \multicolumn{2}{|c|}{$(\text { below 1.7) })^{d)}$} \\
\hline Testosterone $(\mathrm{TS}, \mathrm{ng} / \mathrm{dl})^{* * *}$ & 34.3 & \pm 13.4 & 10 & $\sim 60^{d)}$ \\
\hline SHBG (nmol/l) & 60 & \pm 21 & 18.6 & $\sim 117^{d)}$ \\
\hline IGFBP-3 $(\mu \mathrm{g} / \mathrm{ml})$ & 2.90 & $\pm \quad 0.43$ & 2.29 & $\sim 4.17^{d)}$ \\
\hline $\mathrm{Ca}(\mathrm{mg} / \mathrm{dl})$ & 9.2 & $\pm \quad 0.3$ & 8.7 & $\sim 10.1^{d)}$ \\
\hline IP (mg/dl) & 3.8 & $\pm \quad 0.4$ & 2.4 & $\sim 4.3^{d)}$ \\
\hline $\mathrm{Mg}(\mathrm{mg} / \mathrm{dl})$ & 2.2 & 0.2 & 1.8 & $\sim 2.6^{d)}$ \\
\hline
\end{tabular}

Table 2. Nutrient Intake of Subjects $(n=55)$

\begin{tabular}{lcl}
\hline \hline Energy $(\mathrm{kcal})$ & 1679 & \pm 407 \\
Protein $(\mathrm{g})$ & 56.1 & \pm 12.3 \\
Fat $(\mathrm{g})$ & 56.4 & \pm 19.4 \\
Carbohydrate $(\mathrm{g})$ & 229.5 & \pm 53.7 \\
$\mathrm{Ca}(\mathrm{mg})$ & 464 & \pm 176 \\
$\mathrm{Iron}(\mathrm{mg})$ & $6.3 \pm 2.4$ \\
Vitamin A $(\mu \mathrm{g})$ & 428 & \pm 316 \\
Vitamin $\mathrm{B}_{1}(\mathrm{mg})$ & $0.80 \pm 0.30$ \\
Vitamin $\mathrm{B}_{2}(\mathrm{mg})$ & $1.10 \pm 0.30$ \\
Vitamin C $(\mathrm{mg})$ & 81 & \pm 49 \\
Dietary Fiber $(\mathrm{g})$ & 10.9 & \pm 4.4 \\
\hline \multicolumn{2}{c}{ Mean \pm S.D. } & \multicolumn{2}{c}{}
\end{tabular}

statistically significant.

\section{RESULTS}

For each physical activity score from 1 to 5 , there were $26,3,3,10$, and 13 subjects, respectively.

The mean characteristics and biochemical values are shown in Table 1. The subjects were very thin, and none of the subjects had BMI $>25$.

The mean nutrient intakes are shown in Table 2.

The Pearson correlation coefficients between lumbar BMD and other variables are shown in
Table 3. Pearson Correlation Coefficients between Lumbar BMD and Other Variables $(n=55)$

\begin{tabular}{lc}
\hline \hline Age & 0.072 \\
Height & 0.232 \\
Weight & $0.452^{* *}$ \\
$\mathrm{BMI}$ & $0.384^{* *}$ \\
Waist & $0.323^{*}$ \\
$\dot{\mathrm{V}}{ }_{2} \max \left(\mathrm{L} \cdot \mathrm{min}^{-1}\right)$ & $0.332^{* *}$ \\
$\dot{\mathrm{VO}}{ }_{2} \max \left(\mathrm{ml} \cdot \mathrm{kg}^{-1} \cdot \mathrm{min}^{-1}\right)$ & 0.135 \\
$\mathrm{TSH}$ & -0.009 \\
$\mathrm{GH}$ & 0.03 \\
$\mathrm{IGF}-1$ & 0.155 \\
$\mathrm{LH}$ & 0.003 \\
Estradiol & 0.016 \\
Progesterone & -0.11 \\
Testosterone & -0.119 \\
$\mathrm{SHBG}$ & 0.019 \\
$\mathrm{IGFBP}-3$ & $0.327^{*}$ \\
Ca & $-0.411^{* *}$ \\
IP & -0.235 \\
Magnesium & 0.154 \\
\hline${ }^{*} p<0.05,{ }^{* *} p<0.01$. &
\end{tabular}

Table 3 and Fig. 1. Lumbar BMD was significantly positively correlated with body weight, BMI, waist circumference, $\dot{\mathrm{VO}}_{2} \mathrm{max}$ in $\mathrm{ml} \cdot \mathrm{min}^{-1}$, and IGFBP3 level and negatively correlated with serum $\mathrm{Ca}$ 

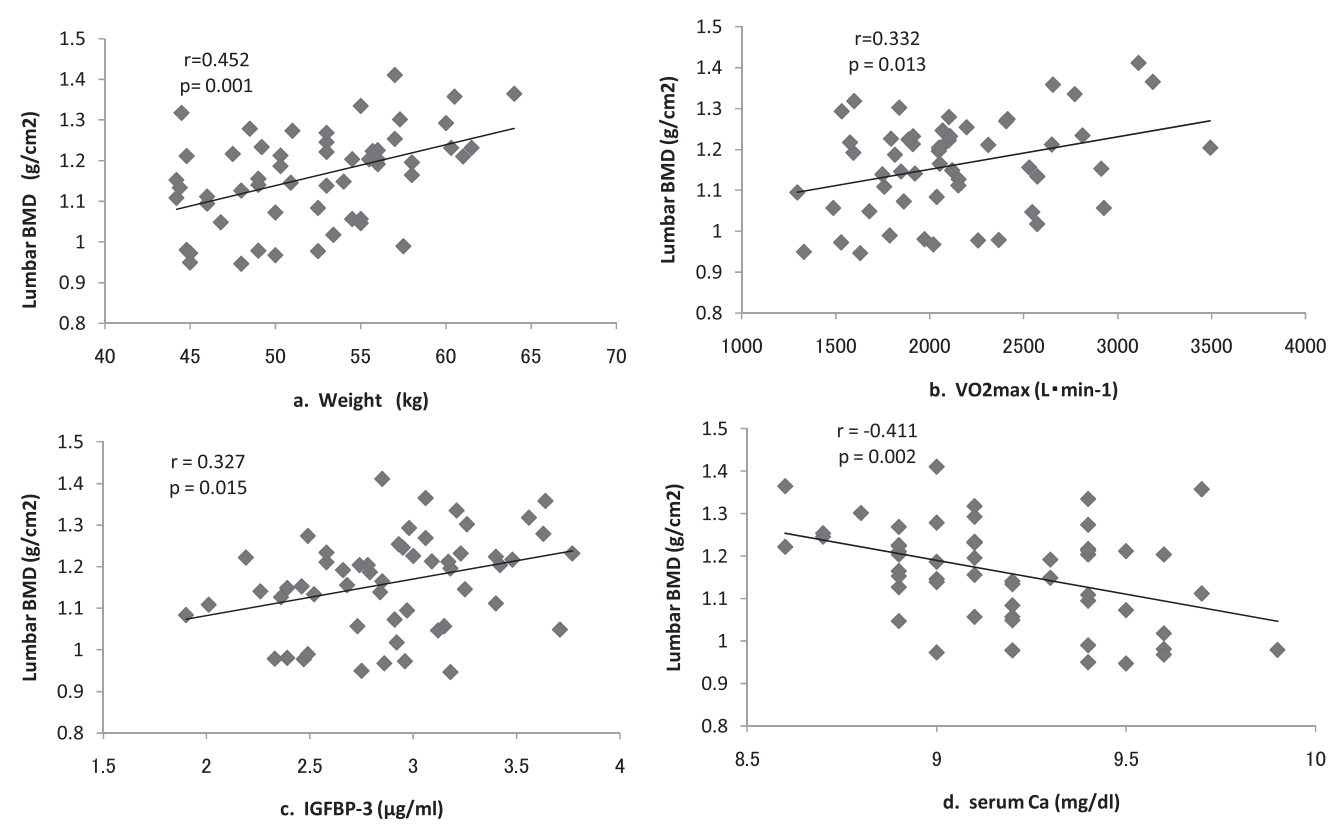

Fig. 1. The Pearson Correlation Coefficients between Lumbar BMD and Body Weight, $\dot{\mathrm{VO}}_{2} \max$ in $\mathrm{L} \cdot \mathrm{min}^{-1}$, IGFBP-3, and Serum Ca in 55 Collegiate Women

Table 4. Standardised Partial Regression Coefficient of Determinants of Lumbar BMD $(n=55)$

\begin{tabular}{llr}
\hline \hline & Body weight & 0.214 \\
& $\dot{\mathrm{VO}}{ }_{2} \max \left(\mathrm{L} \cdot \mathrm{min}^{-1}\right)$ & 0.288 \\
& $\mathrm{IGFBP}-3$ & 0.307 \\
& serum Ca & -0.334 \\
\hline $\mathrm{R}^{2}$ & & 0.430 \\
\hline
\end{tabular}

level. Dietary and nutrient intakes did not significantly correlate with lumbar BMD (data not shown).

When we entered body weight, BMI, waist circumference, $\dot{\mathrm{V}} \mathrm{O}_{2} \mathrm{max}$ in $\mathrm{L} \cdot \mathrm{min}^{-1}$, IGFBP-3 level, and serum $\mathrm{Ca}$ level into the multiple regression analyses as independent variables using lumbar BMD as a dependent variable, body weight, $\dot{\mathrm{VO}}_{2} \mathrm{max}$ in $\mathrm{L} \cdot \mathrm{min}^{-1}$, IGFBP-3 level, and serum $\mathrm{Ca}$ level remained as significant predictors of lumbar BMD (Table 4).

The subjects were divided into 3 groups in accordance with IGFBP-3 level. After adjusting for body weight, $\mathrm{VO}_{2} \max$ in $\mathrm{L} \cdot \mathrm{min}^{-1}$, and serum $\mathrm{Ca}$ level in the analysis of covariance, the group with the highest IGFBP-3 had significantly higher lumbar BMD than the lowest group (Table 5).

\section{DISCUSSION}

Two limitations of our study need to be mentioned. First, the small sample size and the cross- sectional nature of the study do not permit the assessment of causality owing to the uncertain temporality of the association. Second, approximately $99 \%$ of circulating IGFs are bound to 6 specific IGFBPs, which modulate IGF action in a positive or negative manner. For example, IGFBP-4 inhibits while IGFBP-5 stimulates IGF actions in bone cells. ${ }^{3,5)}$ However, we only measured IGFBP-3 level because the majority of circulating IGF-1 is bound to IGFBP-3, which is the quantitatively predominant IGFBP in circulation.

It has been reported that smoking and alcohol intake were inversely associated with IGF-1 levels, ${ }^{22,23)}$ and smokers had significantly lower BMD. ${ }^{23)}$ In the present study, to avoid the confounding influence of these factors, only collegiate women who had never smoked and who drank alcohol less than once a week were admitted to the study. In addition, physical exercise was not allowed $48 \mathrm{hr}$ prior to the blood sampling to avoid the acute effects of exercise, and beverages other than water could not be consumed $24 \mathrm{hr}$ prior to the blood sampling. Furthermore, because GH, IGF1 , and estrogen levels change throughout the menstrual cycle, ${ }^{29,30)}$ blood samples were obtained between days 7 and 9 of the menstrual cycle when estrogen levels were relatively low. ${ }^{25)}$

Physical activity, ${ }^{17-19)}$ and dietary and nutrient intakes, such as $\mathrm{Ca}$, phosphorus, protein, vitamin $\mathrm{D}$, fruit, vegetables, and milk intakes, ${ }^{17-20)}$ have been reported to influence BMD. It has also been reported 
Table 5. Adjusted Mean Values of Lumbar BMD

\begin{tabular}{lccc}
\hline \hline & \multicolumn{3}{c}{ IGFBP-3 } \\
\cline { 2 - 4 } & Low $(n=19)$ & Middle $(n=18)$ & High $(n=18)$ \\
mean & 2.43 & 2.92 & 3.38 \\
range & $(1.90 \sim 2.74)$ & $(2.75 \sim 3.09)$ & $(3.12 \sim 3.77)$ \\
\hline Lumber BMD $\left(\mathrm{g} / \mathrm{cm}^{2}\right)^{a)}$ & $1.128 \pm 0.022$ & $1.160 \pm 0.023$ & $1.198 \pm 0.022^{*}$ \\
range & $(0.978 \sim 1.274)$ & $(0.950 \sim 1.411)$ & $(0.947 \sim 1.358)$ \\
\hline
\end{tabular}

Mean \pm S.E. a) Adjusted for body weight, $\mathrm{V}_{2} \max \left(\mathrm{L} \cdot \mathrm{min}^{-1}\right)$, and serum Ca. ${ }^{*} p<0.05$ vs. Low.

that androgens and estrogen functioned as independent and additive determinants of trabecular BMD in 30 young women aged 18-22. In the present study, however, activity scores, dietary and nutrient intakes, serum sex hormone, and TSH were not significantly correlated with lumbar BMD. Thus, the influences of these variables appear to be limited. These results may be due, at least in part, to the fact that the subjects had a narrow range of these confounding factors.

Physical fitness $^{16)}$ and body weight ${ }^{21,22)}$ are two of the established factors known to be positively correlated with BMD. The results of the present study are in agreement with these studies.

In the present study, serum Ca level was negatively correlated with lumbar BMD even after adjusting for body weight, $\mathrm{VO}_{2}$ max in $\mathrm{L} \cdot \mathrm{min}^{-1}$, and IGFBP-3 level in the multiple regression analyses. This could be due to increased osteoclast activity; however, unfortunately, we did not measure markers of bone resorption, and $\mathrm{Ca}$ homeostasis is not well understood. ${ }^{43)}$

In some studies on Caucasian populations, no association was found between IGF-1 level and BMD in men or women, ${ }^{6-8)}$ while in other studies on Caucasian men, positive correlations were found between IGF-1 and/or IGFBP-3 level and BMD. ${ }^{9-14)}$ Szulc et al. ${ }^{9)}$ reported that IGF-1 level was positively correlated with total hip BMD in men aged 19-65 years. In two other studies, a positive correlation was found between IGF-1 and IGFBP-3 levels and lumbar and/or femoral neck BMD. ${ }^{10,11)}$ Seck et al. ${ }^{12)}$ conducted a 3.3 year follow-up study on 173 elderly men and 107 postmenopausal women and found an association between IGF-1 level and change in femoral neck BMD in women more than 10 years past menopause. Kim et al. ${ }^{13)}$ reported that IGF-1 and IGFBP-3 levels were positively correlated with lumbar and Ward's triangle BMD in Korean postmenopausal women aged 47-60. Although the different results obtained in these studies could be due, at least in part, to racial and sexual differences, these studies are mainly based on middle-aged or older individuals. The results of the present study, focusing on young Japanese women at an age when bone mass reaches its peak, ${ }^{15)}$ show that IGF-1 is not significantly correlated with lumbar BMD. However, IGFBP-3 level was positively correlated with lumbar BMD even after adjusting for body weight, $\dot{\mathrm{V}} \mathrm{O}_{2} \max$ in $\mathrm{L} \cdot \mathrm{min}^{-1}$, and serum $\mathrm{Ca}$ level in the multiple regression analyses. Furthermore, after adjusting for body weight, $\mathrm{V}_{2} \max$ in $\mathrm{L} \cdot \mathrm{min}^{-1}$, and serum $\mathrm{Ca}$ level in the analysis of covariance, the group with the highest IGFBP-3 had significantly higher lumbar BMD than the lowest group. These results are in agreement with a previous study ${ }^{14}$ that focused on healthy men between 25 and 59 years of age. In that study, it was reported that despite the inclusion of established bone mass determinants in both mechanical forces (muscle strength, weight, and physical capacity) and systemic factors [IGF-1, IGFBP-3, $\mathrm{GH}$, parathyroid hormone (PTH), and testosterone], IGFBP-3 level was the dominating explanatory factor for BMD.

In conclusion, IGFBP-3 level was positively correlated with lumbar BMD even after adjusting for confounding factors. Furthermore, after adjusting for body weight, $\dot{\mathrm{VO}}_{2} \max$ in $\mathrm{L} \cdot \mathrm{min}^{-1}$, and serum $\mathrm{Ca}$ level in the analysis of covariance, the group with the highest IGFBP-3 had significantly higher lumbar BMD than the lowest group. The results indicate that the known association of IGFBP3 with lumbar BMD in older adults is already apparent in young women.

Acknowledgements This study was supported by grants from Nakamura Gakuen University and Nakamura Gakuen University Graduate School.

\section{REFERENCES}

1) Blum, W. F., Wikland, K. A., Rosberg, S. and 
Ranke, M. B. (1993) Serum levels of insulin-like growth factor I (IGF-1) and IGF binding protein 3 reflect spontaneous growth hormone secretion. $J$. Clin. Endocrinol. Metab., 76, 1610-1616.

2) Kawai, N., Kanzaki, S., Watou, S. T., Tada, C., Yamanaka, Y., Miyata, T., Oka, M. and Seino, Y. (1999) Serum free insulin-like growth factor I (IGF1), total IGF-1 and IGF-binding protein-3 concentrations in normal children and children with growth hormone deficiency. J. Clin. Endocrinol. Metab., 84, 82-89.

3) Jehle, P. M., Schulten, K., Schulz, W., Jehle, D. R., Stracke, S., Manfras, B., Boehm, B. O., Baylink, D. J. and Mohan, S. (2003) Serum levels of insulinlike growth factor (IGF)-1 and IGF binding protein (IGFBP)-1 to 6 and their relationship to bone metabolism in osteoporosis patients. Eur. J. Intern. Med., 14, 32-38.

4) Wuster, C., Blum, W. F., Schlemilch, S., Ranke, M. B. and Ziegler, R. (1993) Decreased serum levels of insulin-like growth factors and IGF binding protein 3 in osteoporosis. J. Intern. Med., 234, 249-255.

5) Yamaguchi, T., Kanatani, M., Yamauchi, M., Kaji, H., Sugishita, T., Baylink, D. J., Mohan, S., Chihara, K. and Sugimoto, T. (2006) Serum levels of insulinlike growth factor (IGF); IGF-binding protein-3, -4 and -5 ; and their relationships to bone mineral density and the risk of vertebral fractures in postmenopausal women. Calcif. Tissue Int., 78, 18-24.

6) Amin, S., Riggs, B. L., Atkinson, E. J., Oberq, A. L., Melton, L. J., 3rd and Khosla, S. (2004) Apotentially deleterious role of IGFBP-2 on bone density in aging men and women. J. Bone Miner. Res., 19, 1075-1083.

7) Karasik, D., Rosen, C. J., Hannan, M. T., Broe, K. E., Dawson-Hughes, B., Gagnon, D. R., Wilson, P. W., Visser, M., Langlois, J. A., Mohan, S. and Kiel, D. P. (2002) Insulin-like growth factor binding proteins 4 and 5 and bone mineral density in elderly men and women. Calcif. Tissue Int., 71, 323-328.

8) Martini, G., Valenti, R., Giovani, S., Franci, B., Campaqna, S. and Nuti, R. (2001) Influence of insulin-like growth factor-1 and leptin on bone mass in healthy postmenopausal women. Bone, 28, 113117.

9) Szulc, P., Joly-Pharaboz, M. O., Marchand, F. and Delmas, D. (2004) Insulin-like growth factor-1 is a determinant of hip bone mineral density in men less than 60 years of age: MINOS Study. Calcif. Tissue Int., 74, 322-329.

10) Krassas, G. E., Papadopulou, P., Koliakos, G., Konstantinidis, T. and Kalothetou, K. (2003) Growth hormone, insulin-like growth factor-1, and igf binding protein-3 axis relationship with bone mineral density among healthy men. Arch. Androl., 49, 191-199.

11) Gillberg, P., Olofsson, H., Mallmin, H., Blum, W. F., Ljunghall, S. and Nilsson, A. G. (2002) Bone mineral density in femoral neck is positively correlated to circulating insulin-like growth factor (IGF)1 and IGF-binding protein (IGFBP)-3 in Swedish men. Calcif. Tissue Int., 70, 22-29.

12) Seck, T., Scheidt-Nave, C., Leidig-Bruckner, G., Ziegler, R. and Pfeilschifter, J. (2001) Low serum concentrations of insulin-like growth factor-1 are associated with femoral bone loss in a populationbased sample of postmenopausal women. Clin. Endocrinol. (Oxf.), 55, 101-106.

13) Kim, J. G., Shin, C. S., Choi, Y. M., Moon, S. Y. and Lee, J. Y. (1999) The relationship among circulating insulin-like growth factor components, biochemical markers of bone turnover and bone mineral density in postmenopausal women under the age of 60. Clin. Endocrinol. (Oxf.), 51, 301-307.

14) Johansson, A. G., Forslund, A., Hambraeus, L., Blum, W. F. and Ljunghall, S. (1994) Growth hormone-dependent insulin-like growth factor binding protein is a major determinant of bone mineral density in healthy men. J. Bone Miner. Res., 9, 915921.

15) Bonjour, J., Theintz, G., Bertrand, B., Slosman, D. and Rizzoli, R. (1991) Critical years and stages of puberty for spinal and femoral bone mass accumulation during adolescence. J. Clin. Endocrinol. Metab., 73, 555-563.

16) Kelly, P. J., Eisman, J. A., Stuart, M. C., Pocock, N. A., Sambrook, P. N. and Gwinn, T. H. (1990) Somatomedine-C, physical fitness, and bone density. J. Clin. Endocrinol. Metab., 70, 718-723.

17) Fehily, A. M., Coles, R. J., Evans, W. D. and Elwood, P. C. (1992) Factors affecting bone density in young adults. Am. J. Clin. Nutr., 56, 579-586.

18) Hirota, T., Nara, M., Ohguri, M., Manago, E. and Hirota, K. (1992) Effect of diet and lifestyle on bone mass in Asian young women. Am. J. Clin. Nutr., 55, 1168-1173.

19) Metz, J. A., Anderson, J. J. B. and Gallagher, P. N., Jr. (1993) Intakes of calcium, phosphorus, and protein, and physical activity level are related to radial bone mass in young adult women. Am. J. Clin. Nutr., 58, 537-542.

20) Prynne, C. J., Mishra, C. D., O’Connell, M. A., Muniz, G., Laskey, M. A., Yan, L., Prentice, A. and Ginty, F. (2006) Fruit and vegetable intakes and bone mineral status: a cross-sectional study in 5 age and sex cohorts. Am. J. Clin. Nutr., 83, 1420-1428. 
21) Henderson, N. K., Price, R. I., Cole, J. H., Gutteridge, D. H. and Bhagat, C. I. (1995) Bone density in young women is associated with body weight and muscle strength but not dietary intakes. J. Bone Miner. Res., 10, 384-393.

22) Mazess, R. B. and Barden, H. S. (1991) Bone density in premenopausal women: effects of age, dietary intake, physical activity, smoking, and birthcontrol pills. Am. J. Clin. Nutr., 53, 132-142.

23) Karl, J. P., Alemany, J. A., Koenig, C., Kraemer, W. J., Frystyk, J., Flyvbjerg, A., Young, A. J. and Nindl, B. C. (2009) Diet, body composition, and physical fitness influences on IGF-1 bioactivity in women. Growth Horm. IGF Res., 19, 491-496.

24) Buchanan, J. R., Myers, C., Lloyd, T., Leuenberger, P. and Demers, L. M. (1988) Determinants of peak trabecular bone density in women: the role of androgens, estrogen, and exercise. J. Bone Miner. Res., 3, 673-680.

25) Lyons Wall, P. M., Choudhury, N., Gerbrandy, E. A. and Truswell, A. S. (1994) Increase of high-density lipoprotein cholesterol at ovulation in healthy women. Atherosclerosis, 105, 171-178.

26) Young, D. R. and Steinhardt, M. A. (1993) The importance of physical fitness versus physical activity for coronary artery disease risk factors: a crosssectional analysis. Res. Q. Exerc. Sport, 64, 377384.

27) Imamura, H., Katagiri, S., Uchida, K., Miyamoto, N., Nakano, H. and Shirota, T. (2000) Acute effects of moderate exercise on serum lipids, lipoproteins, and apolipoproteins in sedentary young women. Clin. Exp. Pharmacol. Physiol., 27, 975-979.

28) Resources Council of the Science and Technology Agency (Ed.) (2001) The $5^{\text {th }}$ Revised Edition of Tables of Japanese Foodstuff Composition, Ishiyaku Press, Tokyo (in Japanese).

29) Gleeson, H. K. and Shalet, S. M. (2005) GH responsiveness varies during the menstrual cycle. Eur. J. Endocrinol., 153, 775-779.

30) Ovesen, P., Vahl, N., Fisker, S., Veldhuis, J. D., Christiansen, J. S. and Jørgensen, J. O. L. (1998) Increased pulsatile, but not basal growth hormone secretion rates and plasma insulin-like growth factor I levels during the periovulatory interval in normal women. J. Clin. Endocrinol. Metab., 83, 16621667.

31) Ishiwatari, N., Demura, R., Jihiki, K., Odagiri, E. and Demura, H. (1990) Fundamental and clinicalevaluations of sensitive GH kit Daiichi, D-9111. Clin. Endocrinol., 38, 601-606 (in Japanese).

32) Oda, T., Izumi, K., Yoshimura, S., Hara, T.,
Kawano, H., Matsumoto, C., Yahagi, M. and Ohno, T. (1998) Practical application of coated tube method Estradiol Radioimmunoassay kit to fertilization of egg in vitro. World Obstet. Gynecol., 41, 341-345 (in Japanese).

33) Makino, T., Oka, N. and Hara, T. (1998) Studies on alternation of serum estradiol and progesterone in women measured by new coated tube kits. Clin. Endocrinol., 36, 975-979 (in Japanese).

34) Irahara, M., Yasui, T., Higashi, K. and Aono, T. (1998) Fundamental studies on immunoradiometric assays (SPAC-S LH, SPAC-S FSH) for measurement of serum LH and FSH using the pituitary gonadotropin standards. Clin. Endocrinol., 36, 1223 1230 (in Japanese).

35) Tanaka, T., Furuta, I., Aihara, T., Tanaka, S., Satou, H., Himoto, M., Keira, M., Hayashi, M. and Fujimoto, S. (1989) Determination of total blood testosterone concentration by coated tube method (Coat-A-Count TOTAL TESTOSTERONE), and basic examinations on specificity of antitestosterone antibody of the kit. Clin. Endocrinol., 37, 961-964 (in Japanese).

36) Yoshida, K., Sakurada, T., Umise, K., Umise, N., Fukazawa, Y., Nomura, T., Itagaki, Y., Yamamoto, T. and Saitou, S. (1986) Fundamental and clinical study on serum TSH using a TSH RIABEAD II kit. Clin. Endocrinol., 34, 663-667 (in Japanese).

37) Hasegawa, Y., Koshin, E. and Hasegawa, Y. (1995) IGFBP-3 measurements by DSL IRMA. Clin. Endocrinol., 43, 205-209 (in Japanese).

38) Suwa, S. (1991) Clinical evaluation of a new kit for IGF-I (somatomedin C) assay. Clin. Endocrinol., 39, 951-954 (in Japanese).

39) Aoki, N., Fuchi, I., Morita, O., Oomachi, K., Zatuga, T., Imamura, M., Ohno, K., Maruyama, N., Yamamoto, T. and Hiramatsu, H. (1988) Physiologial alteration of sex-hormone-binding globulin in serum with age, sex and pregnancy. Clin. Endocrinol., 36, 1069-1074 (in Japanese).

40) Connerty, H. V. and Briggs, A. R. (1966) Determination of serum calcium by means of orthocresolphthalein complexone. Am. J. Clin. Pathol., 45, 290296.

41) Drewes, P. A. (1972) Direct colorimetric determination of phosphorus in serum and urine. Clin. Chim. Acta., 39, 81-88.

42) Kitamura, M. (1974) The Practice of Clinical Chemistry, Ishiyaku Press, pp. 166-171 (in Japanese).

43) Talmage, R. V. and Talmage, D. W. (2006) Calcium homeostasis, solving the solubility problem. J. Musculoskelet. Neuronal Interact., 6, 402-407. 